[DOI: 10.24214/jecet.A.9.2.30814.]

Jaurnal of Environmental Science, Computer Science and Engineering \& Technology

An International Peer Review E-3 Journal of Sciences and Technology

Available online at www.jecet.org

Section A: Environmental Science

Research Article

\title{
Proximate Analysis and Mineral Composition of Selected Root Crops as a Source of Energy in Poultry Diets
}

\author{
Albino N. Taer ${ }^{1} \&$ Erma C. Taer ${ }^{2}$ \\ ${ }^{1,2}$, Surigao State College of Technology-Mainit Campus
}

Received: 25 March 2020; Revised: 20 April 2020; Accepted: 25 April 2020

\begin{abstract}
In the pursuit of high-quality alternative sources of energy in poultry diets, the locally available root crops Cyrtosperma merkusii and Dioscoreae hispida were studied to ascertain their proximate nutritional and a few mineral values. The $C$. merkusii and $D$ hispida tubers were collected from swamps and secondary forests of the municipalities of Mainit and Alegria, Surigao del Norte, Philippines. Tubers were processed and analyzed in triplicates by procedures of the Association of Official Analytical Chemists (AOAC, 2002) in the determination of Moisture Content, CP, Crude Fiber, Crude Fat, Ash, NFE, calcium, and phosphorus. The result showed that C. merkusii was significantly $(P<0.05$ ) highest $5.90 \%$ compared to D. hispida $4.38 \%$ CP. The calculated M.E. was $2,635.58 \mathrm{Kcal} / \mathrm{kg}$ C. merkusii and 2,304.29 Kcal $/ \mathrm{kg} D$. hispida and crude fiber was $7.15 \%$ for C. merkusii while $2.76 \%$ for D. hispida tuber. However, the crude fat and ash were significantly lesser in C. merkusii $(0.06 \%$ \& $4.82 \%)$ over D. hispida $(0.24 \%$ \& $9.57 \%)$ respectively. Moreover, other significant value results of $C$. merkusii versus $D$. hispida were; MC (13.91 vs. 19.61), NFE (66.12 vs. 63.44$)$, calcium $(0.50$ vs. 0.30$)$ while potassium was not significant $(P>$ 0.05). The herein result implied that $C$. merkusii and D. hispida of Surigao del Norte was a good source of crude protein, crude fat, crude fiber, ash, nitrogen-free extract, metabolizable energy, calcium, and phosphorus an ideal alternative sources of energy for the formulation of good quality and well-balanced diets for poultry feeding.
\end{abstract}

Keywords: Cyrtosperma merkusii, Dioscoreae hispida, proximate analysis, minerals, root crops 


\section{INTRODUCTION}

The poultry feed industry largely anchored to cereal grains mainly maize (corn) as sources of energy in feeding poultry. Through the years, the supplies of corn are becoming insufficient, high priced along with the competition with the human food and biofuel industries. The shortage of energy and protein feeds for monogastric animals that compete with humans for the same class of foodstuff has led to massive importation of cereals and other resources. As a result, the insistent need for alternative sources of energy for poultry is becoming increasingly important. This also calls for a decisive research effort on alternative feed resources to satisfy both humans and animals. Root crops have shown great promise as novel and cheaper alternative energy to maize in developing countries. It has been shown that the efficient use of root crop products reduces the feed costs for poultry production. Starchy root crops and tubers are essential food next to cereals as globally acclaimed sources of carbohydrates. They provide a major part of the world's food supply and are also a prime source of animal feed and processed products for human consumption and industrial use ${ }^{[1]}$. Nutritionally, roots and tubers have a great probability to provide economical sources of dietary energy, particularly carbohydrates.

The root crop [Cyrtosperma merkusii (Hassk.) Schott. 1857] is a starchy underground stem. Its skin is brown and hairy with concentric rings of leaf scars and scales, and its flesh can be white, pink, or purple ${ }^{[2]}$. Taro corms are also currently utilized as animal feeds ${ }^{[3]}$. Like other root crops, taro corm is low protein content and low fat, but higher in carbohydrate.

Additionally, a wildly grown root crop (Dioscoreae hispida Dennst. 1818) is one of the most economically important yam species, which serves as a staple food for millions of people in the tropical and subtropical countries ${ }^{[4]}$, and is categorized as a wild creeping and climbing plant that grows up to $20 \mathrm{~m}$ in height. $D$. hispida is more often grown in secondary forests and found in shaded fields or near streams, which is locally named as Umbi Gadung ${ }^{[5]}$.

In the Province of Surigao del Norte, the Philippines, particularly in the municipality of Mainit is auspiciously endowed with a variety of underdeveloped Cyrtosperma merkusii and a wild but edible root crop (when properly processed) like Dioscoreae hispida. Unfortunately, to date, these ancient crops are underdeveloped, uncultivated, and will probably be lost through neglect. The aim of this study, therefore, was to provide information on energy values, nutrient composition and a few mineral constituents of this uncultivated Cyrtosperma merkusii and Dioscoreae hispida (wild) specie. This was intending to find out its nutritional potential for poultry feeding.

\section{MATERIALS AND METHODS}

Location: The present study utilized selected root crops as potential feedstuffs with a limited scope on sources of energy. The selection of the feedstuffs to be covered was based on the availability of uncultivated, wildly grown and seldom use root crops for human consumption in the Province of Surigao del Norte. The study was carried out at Surigao State College of Technology - Mainit Campus at Magpayang, Mainit, Surigao del Norte, Philippines. Mainit is located on $9^{\circ} 32^{\prime}$ North, $125^{\circ} 31^{\prime}$ East $(9.5378,125.5225)$ and 47.9 meters $(157.2$ feet) above sea level.

Sample collection: The samples of root crops Cyrtosperma merkusii and Dioscoreae hispida were collected from swamp areas and secondary forests of the municipalities of Mainit and Alegria under the Province of Surigao del Norte, Philippines. The C. merkusii corms were thoroughly washed with tap water, hand peeled and chopped finely by hand. Thereafter, the corm's chips were oven-dried for two (2) hours at a high temperature of about $100^{\circ} \mathrm{C}$ until moisture content stabilizes or chips turn brown. The preparation of $D$. hispida was based on ${ }^{[6]}$ formula where outer root skin was removed by 
a sharp knife, thinly chopped (approximately $2 \mathrm{~cm}$ ), washed thoroughly and cooked in water (i.e., fresh tubers were added in boiling water at a ratio of 1:1, wt/vol) for 2 hours. The cooking water was removed two (2) times, and the cooked tubers were then sun-dried. All root crops chips were grounded and packed via air-tight plastic containers for submission to analysis.

Proximate analysis: The standard methods of the Association of Official Analytical Chemists were applied to verify the moisture, crude protein, crude fat, total ash, crude fiber, nitrogen-free extract (NFE), calcium and phosphorus contents of each sample AOAC $2002{ }^{[7]}$. The crude protein was determined by the Kjeldahl method, estimated total energy (Gross Energy) were based on Atwater's Physiological Fuel Value and the metabolizable energy (ME) was estimated as $81 \%$ of the gross energy (GE) for both Palau and Wild Yam. Each analysis was carried out in triplicate.

Moisture content; Using the pre-weighed aluminum dish (with cover), the two (2 gm) samples were placed on it, shook and evenly distributed. Immediately thereafter, the dish covers were removed and samples were placed in an oven and dry at $135^{\circ} \mathrm{C}$ for 2 hours and transferred to desiccators to cool and then weighed to measure the $\%$ moisture content.

Crude Protein: The crude proteins in root crops samples were determined by Kjeldahl method using 1.00gram samples in a flask containing a considerable amount of catalysts and sulfuric acid and digested for 2.5 hours. Through the distillation process, ammonium hydroxide was trapped as ammonium borate in a boric acid solution was titrated against $0.1 \mathrm{NH} 4 \mathrm{Cl}$ and by multiplying with 6.25 percentages of nitrogen was converted into protein.

Crude Fat: The two (2) gram of dried sample was obtained with petroleum ether $(150 \mathrm{~mL})$ for 5 hours at a rate of $10 \mathrm{cycles} / \mathrm{h}$. Petroleum ether was evaporated within 30 minutes using the hot air system of the Soxflo instrument or the rotary evaporator at $50^{\circ} \mathrm{C}$ after the extraction of Soxhlet. The round-bottom flasks were then dried at $100^{\circ} \mathrm{C}$ for 1 hour, and the content of fat was gravimetrically determined.

Crude Fiber: Approximately two (2) gram root crops were mixed with $1.25 \%$ sulfuric acid solution was placed in $250 \mathrm{ml}$ capacity flask was heated for about 30 minutes, then filtered until traces of acid could not be detected using $\mathrm{pH}$ paper. The extracted acid was moved to a flask of $250 \mathrm{ml}$ and subsequently added 1.25 percent Sodium hydroxide. Reheated the samples for 30 minutes, then washed and filtered. The material was moved at $120^{\circ} \mathrm{C}$ for 12 hours to the crucible and dry oven. After that crucible was put at $550^{\circ} \mathrm{C}$ for 12 hours in the muffle oven and registered the weight of the crucible.

Ash: Determination of ash content was homogeneous to that of analysis of moisture. $2 \mathrm{~g}$ specimen was placed in a pot, weighed and put in muffle furnace overnight at $550^{\circ} \mathrm{C}$.

Estimated Energy: The estimated total energy (Gross Energy) were based on Atwater's Physiological Fuel Value (fats - $9 \mathrm{Kcal} / \mathrm{g}$, protein $-4 \mathrm{Kcal} / \mathrm{g}$, and carbohydrate $-4 \mathrm{Kcal} / \mathrm{g}$ ) and the metabolizable energy (ME) was estimated as $81 \%$ of the gross energy (GE) for both Cyrtosperma merkusii and Dioscoreae hispida samples.

Calcium: Weigh $2 \mathrm{~g}$ finely ground sample into a porcelain platter and ash residues. Add $40 \mathrm{ml}$ hydrochloric acid and a little drop of nitric acid to the residue, boll, cool and transfer to a graduated cylinder of $250 \mathrm{ml}$ volume capacity. Dilute to volume and mix. The aliquot of the solution was pipet into a cup and was attenuated to $100 \mathrm{ml}$ and add 2 drops of methyl red. A drop of aluminum solution was added until turn brown color and adjoining two drops of HCL making it pink in color. The diluted solution with added $10 \mathrm{ml}$ of $4.2 \%$ hot aluminum oxalate solution was boiled, stirred, and $\mathrm{pH}$ adjusted. The settled precipitate was filtered and washed with $\mathrm{Al}(\mathrm{OH}) 3$ solution. The precipitate in a 
filter paper was back in baker and mixed with water $(125 \mathrm{ml})$ with $5 \mathrm{ml} \mathrm{H} 2 \mathrm{SO} 4$ and heated to max. $70^{\circ} \mathrm{C}$ and titrate against the standard permanganate solution.

Phosphorous: Pipette and a fraction of the specimen solution prepared apropos to calcium determination into a $100 \mathrm{ml}$ flask and add $20 \mathrm{ml}$ of the molybdovanadate reagent. Makeup, blend and stand up to volume for 10 minutes. Transfer regular aliquots containing $0.5,0.8,1.0$ and $1.5 \mathrm{mg}$ of phosphorus to $100 \mathrm{ml}$ flasks, and repeat as above. Write sample at $400 \mathrm{~mm}$ setting a 100 percent transmission level of $0.5 \mathrm{mg}$. Determine $\mathrm{mg}$ phosphorus from a standard curve at each sample aliquot.

Statistical analysis: One-way analysis of variance (ANOVA) was conducted on each of the processing methods and Tukey's HSD test at a significant level of $p<0.05$ was performed using SPSS version 20 software for windows to compare the difference between treatment means. The results were expressed as means + standard deviation of three separate tests.

\section{RESULTS}

The data on the proximate composition of Cyrtosperma merkusii and Dioscoreae hispida root meals are presented in Table 1. Both tested samples have significantly different nutritional composition except the phosphorus contents which are not significantly different at the $5 \%$ level. The result shows the $C$. merkusii tuber has significantly higher crude protein $(\mathrm{CP})$ content of $5.94 \%$ compared to $D$. hispida root at $4.38 \%$. The metabolizable energy (M.E.) is $2,635.58 \mathrm{Kcal} / \mathrm{Kg}$ in C. merkusii higher against $D$. hispida having $2,304.29 \mathrm{Kcal} / \mathrm{Kg}$. Between the two root crops, the $C$. merkusii has a significantly higher crude fiber of $7.15 \%$ compared to D. hispida has $2.76 \%(P<0.05)$. However, the means of crude fat and ash $(0.06 \% \& 4.82 \%)$ have significantly lesser values in $C$. merkusii tuber contrary to the D. hispida roots having 0.24 and $9.57 \%$ in crude fat and ash content respectively. Moreover, other significant analysis results of $C$. merkusii versus D. hispida are the following; moisture content ( $13.91 \%$ vs. $19.61 \%)$, nitrogen-free extract $(66.12 \%$ vs. 63.44$)$, calcium $(0.50 \%$ vs. $0.30 \%)$.

Table 1: Mean and standard deviations of proximate and mineral content of $C$. merkusii and $D$. hispida root meal.

\begin{tabular}{lcc}
\hline \multicolumn{1}{c}{ Constituents } & Sample & \\
& C. merkusii & D. hispida \\
\hline Moisture & $13.91 \pm 1.03^{\mathrm{a}}$ & $19.61 \pm 1.20^{\mathrm{b}}$ \\
Ash & $4.82 \pm 0.05^{\mathrm{a}}$ & $9.37 \pm 0.32^{\mathrm{b}}$ \\
Crude protein & $5.94 \pm 0.09^{\mathrm{b}}$ & $4.38 \pm 0.20^{\mathrm{a}}$ \\
Crude fiber & $7.15 \pm 0.00^{\mathrm{b}}$ & $2.76 \pm 0.04^{\mathrm{a}}$ \\
Crude Fat & $0.063 \pm 0.005^{\mathrm{a}}$ & $0.24 \pm 0.010^{\mathrm{b}}$ \\
Nitrogen free extract & $68.12 \pm 0.020^{\mathrm{b}}$ & $63.44 \pm 0.030^{\mathrm{a}}$ \\
Metabolizable energy & $2635.58 \pm 0.070^{\mathrm{b}}$ & $2304.29 \pm 0.060^{\mathrm{a}}$ \\
Calcium & $0.50 \pm 0.040^{\mathrm{b}}$ & $0.30 \pm 0.010^{\mathrm{a}}$ \\
Phosphorus & $0.073 \pm 0.055^{\mathrm{ns}}$ & $0.080 \pm 0.010^{\mathrm{ns}}$ \\
\hline
\end{tabular}

Means \pm SD values with different letters within the same row differ significantly

${ }^{\text {ns }}$ Not significant 


\section{DISCUSSIONS}

Moisture: Moisture (expressed on a dry weight basis) content was generally high and ranged from $13.91 \%$ for C. merkusii and $19.61 \%$ for D. hispida as higher moisture content is a known characteristic feature of root and tubers crops. This study showed that the moisture content of the root crops tested was higher than thus have been presented in the literature, i.e.: moisture of $C$. merkusii 10.9 - $11.6^{[8]}$ and D. bulbifera and D dumentorum 6.53 to $7.02^{[9]}$.

Ash: The total ash of D. hispida root was significantly higher (9.37\%) versus the ash content in $C$. merkusii tuber $(4.84 \%)$. This was greater than or equal to $2.60-6.32 \%{ }^{[10]}, 2.48$ to $8.50 \%{ }^{[11]} .50$ to $3.70 \%{ }^{[8]}, 3.20 \%{ }^{[12]}, 4.71 \%{ }^{[13]}$ but significantly greater in values of yams and Xanthosoma $s p(0.25-$ $2.33 \%$ ) presented Senanayake et al., ${ }^{[14]}$, and 1.40 to $1.60 \%{ }^{[15]}$.

Crude protein: The C. merkusii and Dioscorea tubers are rich sources of carbohydrate and protein. The mean scores of crude protein values are rather low, ranging from $4.38 \%$ for the D. hispida roots and $5.94 \%$ for the C. merkusii tubers. These were similar in values $5.90 \% \mathrm{CP}$ reported Zaid \& Sogbesan ${ }^{[12]}$ to those of Colocasia, a bit lower values $7.93 \%$ reported Okon et al., ${ }^{[13]}$ of $C$. chamissonis, but much lower value ranged from 8.10 to $9.00 \%$ result Nguimbou et al., ${ }^{[8]}$ of $C$. merkusii and 6.48 to $13.42 \%$ result Mohan et al., ${ }^{[10]}$ of some Dioscoreae spp. However, these differences can be expected due to varietal and geographical differences.

Crude fiber: Crude fiber content ranges from $2.76 \%$ to $7.15 \%$ of DM. Between these feedstuffs, $D$. hispida had the lowest crude fiber content, while $C$. merkusii had the highest. These values, however, fall within $3.21 \%$ to $9.21 \%$ ranges of Dioscoreae spp. ${ }^{[10,11]}, 2.20 \%$ to $3.60 \%$ of $C$. merkusii ${ }^{[8]}, 2.86 \%$ of Colocasia ${ }^{[12]}$, but higher $1.36 \%$ of $C$. chamissonis ${ }^{[13]}$.

Crude fat: The crude fat content of tested tubers used in this study was lower than the range of crude fat contents which were presented by Adane et al., ${ }^{[16]}$ for raw, boiled and fermented taro in Ethiopia and Nguimbou et al., ${ }^{[8]}$ for the yellow and white portion of giant swamp taro tubers. The crude fat of Dioscoreae hispida $(0.24 \%)$ was significantly different $(P<0.05)$ from the crude protein of $C$. merkusii $(0.06 \%)$.

Nitrogen free extract: The result for analysis of nitrogen-free extract (NFE) of tubers was found to be in adequate levels $63.44-68.12 \%$ correspondingly for D. hispida and C. merkusii. These levels are lesser than $65.47 \%$ to $86.20 \%{ }^{[11]}$ and $72.06 \%$ to $79.79 \%$ by ${ }^{[10]}$ reports.

Metabolizable energy: Metabolizable energy (ME) is the amount of energy in a feed that is available to the animal for use. The C. merkusii tubers were found higher $2635.58 \mathrm{Kcal} / \mathrm{kg}$ of ME content compared $2304.29 \mathrm{Kcal} / \mathrm{kg}$ of $D$. hispida roots in this trial that fall behind the values for differently processed (raw, soaked, cooked, and fermented) C. esculenta tubers $(2943.70-2966.82 \mathrm{Kcal} / \mathrm{kg})$ M.E. reported ${ }^{[17]}$, Manihot esculenta presented by various authors, with values ranging from 3,000 Kcal/ $\mathrm{kg}$ to $3,200 \mathrm{kcal} / \mathrm{kg}^{[18]}, 3,200 \mathrm{kcal} / \mathrm{kg}^{[19]}, 3,145 \mathrm{kcal} / \mathrm{kg}{ }^{[20]}, 3,279 \mathrm{kcal} / \mathrm{kg}{ }^{[21]}$, and $3852.00 \mathrm{Kcal} / \mathrm{kg}{ }^{[22]}$. However, these values exceeded $2280.00 \mathrm{Kcal} / \mathrm{kg}{ }^{[23]}$ for Dioscorea rotundata peels.

Calcium: Calcium plays a major role in the absorption of nutrients as well as in blood clotting. The result shows that $C$. merkusii have more calcium than D. hispida having $0.50 \%$ and $0.30 \%$ respectively, a slightly lesser value of $0.60 \%{ }^{[23]}, 1.20 \%$ to $2.41 \%{ }^{[24]}$ while lesser than or equal to $0.32 \%$ to $0.52 \%$ for D. bulbifera and D. dumentorum ${ }^{[9]}$.

Phosphorus: Phosphorus plays a significant part in the way carbohydrates and fats are used in the body. Protein for the growth, support and repair of cells and tissues is also needed for the body to produce. The phosphorus between the tested tubers was not significantly different $(P \geq 0.05)$ showing 
$0.073 \%$ for C. merkusii and $0.080 \%$ for $D$. hispida where have much lesser values in the previous results by ${ }^{[24,9]}$ having $0.39 \%$ to $1.00 \%$ and $0.86 \%$ to $0.81 \%$ respectively.

\section{CONCLUSION}

Based on the result of proximate analysis studies of $C$. merkusii and D. hispida tubers it can be summarized that both of them are found to be a good source of crude protein, crude fat, crude fiber, ash, nitrogen-free extract, metabolizable energy, calcium and phosphorus, an ideal nutrient composition for alternative sources of energy in the formulation of high-quality and well-balanced poultry diets.

\section{REFERENCES}

1. A. Chandrasekara \& T. Josheph Kumar, Roots and tuber crops as functional foods: a review on phytochemical constituents and their potential health benefits. International journal of food science, 2016.

2. M.S.Strauss, M. S. (1983). Anatomy and morphology of taro, Colocasia esculenta (L.) Schott. 1983

3. J.K.Wang, \& S. Higa, Taro, a review of Colocasia esculenta and its potentials. Honolulu: University of Hawaii Press.1983,

4. E.A.Udensi, H.O. Oselebe \& O.O. Iweala, The investigation of chemical composition and functional properties of water yam (Dioscorea alata): effect of varietal differences. Pakistan Journal of Nutrition, 2008,7(2), 342-344.

5. M. Nashriyah, Y. Nornasuha, T. Salmah, N. Norhayati \& M. Rohaizad, Dioscorea hispida Dennst (Dioscoreaceae): An overview. Buletin UniSZA, 2010.

6. H.K.Dei, A. Bacho, J. Adeti \& S.P. Rose, Nutritive value of false yam (Icacina oliviformis) tuber meal for broiler chickens. Poultry Science, 2011, 90(6), 1239-1244.

7. AOAC - Association of Official Analytical Chemistry. 2005. Official methods of analysis. AOAC International, Arlington, VA, 2005.

8. R.M. Nguimbou, T. Boudjeko, N.Y. Njintang, M. Himeda, J. Scher \& C.M. Mbofung, Mucilage chemical profile and antioxidant properties of giant swamp taro tubers. Journal of food science and technology, 2014, 51(12), 3559-3567.

9. M.N.Ogbuagu, Nutritive and antinutritive composition of the wild (in-edible) species of Dioscorea bulbifera (Potato Yam) and Dioscorea dumentorum (Bitter Yam). Journal of Food Technology, 2008, 6(5), 224-226.

10. V.R.Mohan, P.S. Shajeela, L.L. Jesudas \& P.T.Soris, Nutritional and antinutritional evaluation of wild yam (Dioscorea spp.). Tropical and subtropical Agroecosystems, 2011, 14(2), 723-730.

11. S. Shanthakumari,V.R. Mohan \& de J. Britto, Nutritional evaluation and elimination of toxic principles in wild yam (Dioscorea spp.). Tropical and Subtropical Agroecosystems, 2008, 8(3), 319-325.

12. A.A.Zaid \& O.A.Sogbesan, Evaluation and potential of cocoyam as carbohydrate source in catfish, (Clarias gariepinus [Burchell, 1822]) juvenile diets. Afr J Agric Res, 2010, 5, 453-457.

13. B. Okon, L.A. Ibon, E.F. Nsa \& J.A. Ubua, Reproductive and growth traits of parents and F1 hatchings of Achatina achatina (L.) snails under mixed feeding regime with graded levels of swamp taro cocoyam (Cyrtosperma chamissonis) and pawpaw leaves (Carica papaya). Journal of Agricultural Science, 2012, 4(11), 289-298. 
14. S. A. Senanayake, K. K. D. S. Ranaweera, A.Bamunuarachchi \& A. Gunaratne, Proximate analysis and phytochemical and mineral constituents in four cultivars of yams and tuber crops in Sri Lanka. Trop Agric Res Ext, 2012, 15(1), 32-36.

15. I. J. Alinnor \& C. O. Akalezi, Proximate and mineral compositions of Dioscorea rotundata (white yam) and Colocasia esculenta (white cocoyam). Pakistan journal of nutrition, 2010, 9(10), 9981001.

16. T. Adane, A. Shimelis, R. Negussie, B. Tilahun \& G.D.Haki, Effect of processing method on the Proximate composition, mineral content and antinutritional factors of Taro (Colocasia esculenta, L.) growth in Ethiopia. African Journal of Food, Agriculture, Nutrition and Development, 2013, 13(2).

17. R. Olajide, A. O. Akinsoyinu, O. J. Babayemi, A. B. Omojola, A. O. Abu \& K.D. Afolabi, Effect of processing on energy values, nutrient and anti-nutrient components of wild cocoyam (Colocasia esculenta (L.) Schott) corm. Pakistan Journal of Nutrition, 2011, 10(1), 29-34.

18. A. J. A. Buitrago, B. Ospina Patiño, J. L. Gil Llanos \& H. Aparicio, and Cassava root and leaf meals as the main ingredients in poultry feeding: Some experiences in Colombia, 2007.

19. S.S.A.Egena, Effect of different hydrocyanic acid consumption on nutrient digestibility in broilers fed cassava flour meal. In Proceedings of the 11th Annual Conference of Animal Science Association of Nigeria 2006, 153-155.

20. S.Khajarern \& J. Khajarern, Use of cassava products in poultry feeding: roots, tubers, plantains and bananas in animal feeding, 2007

21. T. S. Olugbemi, S. K. Mutayoba, \& F.P.Lekule, Effect of Moringa (Moringa oleifera) inclusion in cassava-based diets fed to broiler chickens. International Journal of Poultry Science, 2010, 9(4), 363-367.

22. E. Tesfaye, G. Animut, M. Urge \& T. Dessie, Cassava root chips as an alternative energy feed ingredient in broiler ration. International Journal of Poultry Science, 2013, 12(5), 298-306.

23. I. M. Haruna, A. S. Muhammad, I.Y.Jabil \& E. Simon, The use of yam peel meals (yam) as a source of energy in concentrate diet for rabbits. International journal of science and applied research (issn: 2504-9070), 2018, 3(1), 45-53.

24. D. E. Okwu \& C. U. Ndu, Evaluation of the phytonutrients, mineral and vitamin contents of some varieties of yam (Dioscorea sp.). International Journal of Molecular Medicine and Advance Science, 2006, 2(2), 199-203.

\section{Corresponding author: ALBINO N. TAER}

Agriculture Technologists, Surigao State College Of Technology- Mainit Campus, Magpayang, Mainit, Surigao Del Norte,Email: albinotaer74@gmail.com

Mobile number: +639109033042

Date of publication on line 25.04.2020 